OPEN ACCESS

Edited by:

Bernard Tardy

INSERM C/C1408, France

Reviewed by:

Renee Eslick,

Canberra Hospital, Australia

${ }^{*}$ Correspondence:

Tiphaine Raia-Barjat

tiphaine.barjat@chu-st-etienne.fr

Specialty section:

This article was submitted to

Thrombosis,

a section of the journa

Frontiers in Cardiovascular Medicine

Received: 17 January 2022

Accepted: 11 February 2022

Published: 07 March 2022

Citation:

Raia-Barjat T, Edebiri $O$ and Ni Ainle F (2022) Preeclampsia and Venous Thromboembolism:

Pathophysiology and Potential

Therapy.

Front. Cardiovasc. Med. 9:856923.

doi: 10.3389/fCVm.2022.856923

\section{Preeclampsia and Venous} Thromboembolism: Pathophysiology and Potential Therapy

\author{
Tiphaine Raia-Barjat ${ }^{1,2 *}$, Osasere Edebiri ${ }^{3}$ and Fionnuala Ni Ainle ${ }^{3,4}$ \\ ${ }^{1}$ Department of Gynecology and Obstetrics, Centre Hospitalier Universitaire de Saint-Étienne, Saint-Étienne, France, \\ 2 INSERM U1059, SAINBIOSE, Université Jean Monnet, Saint-Étienne, France, ${ }^{3}$ Department of Haematology, Mater \\ Misericordiae University Hospital, Rotunda Hospital, Dublin, Ireland, ${ }^{4}$ UCD School of Medicine, University College Dublin, \\ Dublin, Ireland
}

Preeclampsia (PET) is a multisystem inflammatory disorder that represents a leading cause of feto-maternal morbidity and mortality, complicating $2-5 \%$ of all pregnancies. PET incurs an increased risk of venous thromboembolism, which is one of the leading causes of death in pregnancy and in the postpartum period. This prothrombotic phenotype is attributable to the maternal phase of PET, which is characterized by a systemic inflammatory response and coagulation activation. Research continues to be undertaken in terms of preventative measures, however, currently revolves around pharmacological low dose aspirin initiated in the first trimester of pregnancy for those with risk factors. Treatment involves antenatal corticosteroids for fetal lung development in preterm birth, parenteral magnesium sulfate for fetal neuroprotection and maternal seizure prophylaxis, and timely birth of the fetus and placenta being the only definitive treatment of PET. Patients with a venous thromboembolism (VTE) risk deemed to be $>1-$ $3 \%$ are treated with pharmacological thromboprophylaxis in the form of low molecular weight heparin. Completing each woman's VTE risk assessment is crucial, particularly in the setting of PET, as there is also a proven associated competing hemorrhagic risk.

Keywords: preeclampsia, PET, pregnancy, thrombosis, risk

\section{INTRODUCTION}

Preeclampsia (PET) complicates $2-5 \%$ of all pregnancies and represents a leading cause of feto-maternal morbidity and mortality worldwide (1-3). PET is a multi-system inflammatory disorder and is estimated to account for $15 \%$ of maternal mortality worldwide (3-5). The classical clinical presentation of PET consists of the new onset of hypertension and proteinuria after 20 weeks gestation or other maternal organ dysfunction (6-8). Complications of PET include intrauterine growth restriction (IUGR), fetal death (1-2\% of cases), preterm birth, hepatic and renal dysfunction, thrombosis, coagulopathy, eclampsia (a severe manifestation of PET characterized by severe hypertension and generalized seizures) and maternal death (up to 70,000 deaths annually worldwide) (8-10).

Risk factors for PET include history of PET, chronic hypertension, pregestational diabetes mellitus, multiple pregnancy, obesity, and antiphospholipid syndrome $(11,12)$. Women with a history of VTE were also at increased risk of placenta-mediated complications (13). PET pathophysiology is considered to occur in two stages: abnormal placentation in the first 
trimester followed by maternal endothelial dysfunction in the second trimester (14). Crucially, hypertensive disorders in pregnancy are associated with a higher risk of arterial cardiovascular diseases (myocardial infarction and ischemic stroke) in later life (15-17). Moreover, PET is characterized by alterations in pro and anticoagulant pathways (18), beyond the physiological hypercoagulable state that occurs in pregnancy $(19,20)$. This hypercoagulable state may increase venous thromboembolism (VTE) risk (1), a major contributor to maternal morbidity and mortality (21-24). VTE is therefore not only a risk factor but also a consequence of PET (13).

\section{PATHOPHYSIOLOGY OF PREECLAMPSIA}

Preeclampsia pathophysiology is considered to occur in two stages in the first trimester and 2nd/3rd trimester (Figure 1).

Under normal physiological circumstances, the uteroplacental arteries are invaded by endovascular trophoblasts. The caliber of the spiral arteries widens, which facilitates a progressive increase of uteroplacental blood flow; and the tunic of the artery becomes toneless without maternal vasomotor control $(25,26)$. In PET, placental histology is characterized by impaired trophoblast invasion and failure of vascular remodeling (27). Although hypotheses have been proposed, underlying mechanisms remain poorly characterized. Reduced oxygen tension and persistent hypoxia appear to play an important role (28). With impaired spiral artery remodeling, trophoblast cells are exposed to a chronic intermittent hypoxia and reoxygenation phenomenon (29), leading to oxidative stress. Oxidative stress is associated with antioxidant depletion, oxidative damage and an inflammatory response $(30,31)$. Immune mechanisms at the maternal-placental interface may be multifactorial, involving a deficiency of natural killer cells at the beginning of placentation (32), and abnormal allorecognition of paternal HLA-C by the maternal killer Iglike receptors (33). Imbalances of angiogenic factors have also been postulated to play a role, in particular vascular endothelial growth factor (VEGF) which plays a role in vascular remodeling (34). Overall PET heritability is estimated at 55\%, with 30$35 \%$ maternal and $20 \%$ fetal genetic contributions to risk $(35,36)$. Emerging mechanisms hypothesized also to play a pathophysiological role include epigenetic factors, including dysregulation at the Fms-like tyrosine kinase 1 locus in the fetal genome $(37,38)$ or a maternal genome-wide susceptibility locus at rs9478812, which is an intronic region of protein PLEKHGI implicated in blood pressure regulation (39). These myriad pathogenetic processes may also be affected by maternal preexisting characteristics, environmental and physiological factors $(40,41)$. It is plausible that a combination of mechanisms interact to initiate early changes that result in the clinical spectrum of PET.

Circulating factors that enter the maternal circulation as a consequence of abnormal placentation interact with endothelial cells, stimulating structural and functional changes that include altered vascular reactivity to vasomodulator substances, activation of the coagulation cascade and an increase in capillary permeability $(14,42,43)$. Hypertension develops as a consequence of the maternal response to antiangiogenic factors, vasospasm and agonistic autoantibodies that bind to the angiotensin II type 1 receptor (AT1-AAs) (44). In the maternal preeclamptic circulation, excess levels of antiangiogenic factors including soluble Fms-like tyrosine kinase 1 (sFLT1) and soluble endoglin (sENG), coupled with a decrease in physiological levels of proangiogenic proteins including VEGF and placental growth factor (PlGF) result in an overall antiangiogenic state. These markers are used clinically during PET screening in the first trimester, and later as diagnostic or prognostic biomarkers (42, 45-51). The International Federation of Gynecology and Obstetrics (FIGO) recommend the use of this biomarkers in a first- trimester "screen and prevent" strategy for PET (52). Preeclamptic women exhibit a vasoconstrictive state secondary to the release of vasoactive agents such as prostacyclin, thromboxane A2, nitric oxide, and endothelins. Moreover, PET is also a proinflammatory state secondary to (1) systemic release of apoptotic and necrotic trophoblastic placental debris (53), (2) dysregulation in the balance of IL-10 and proinflammatory cytokines including IL-12 and IL-18 (54), and to (3) elevated complement level (55).

Collectively, these processes lead to systemic vascular and maternal organ dysfunction with long-term cardiovascular (56), cognitive (57) and renal (58) effects.

\section{THROMBOEMBOLIC RISK AND PREECLAMPSIA}

Venous thromboembolism (VTE) remains a leading cause of death in pregnancy and in the postpartum period (59). During 2014-2016, VTE was reported to be the top cause of direct maternal death in the United Kingdom and Ireland, occurring in 1.39 (95\% CI 0.95-1.96) per 100,000 pregnancies (60). Women diagnosed with PET are reported to have a variable VTE risk, depending on their pregnancy stage (the highest-risk phase being the postpartum period) and PET severity (likely due to balanced alterations in pro and anticoagulant pathways). However, under some circumstances, women may have an up to five-fold increased risk of VTE compared to the normal pregnancy-associated VTE risk reported in the population (10).

Under normal physiological circumstances, pregnancy is characterized by the development of a hypercoagulable state, characterized by an increase in procoagulant factor activity and a down-regulation of endogenous anticoagulant and fibrinolytic pathways. It is postulated that this hypercoagulable state develops to limit the risk of major bleeding associated with labor and birth $(61,62)$. Although this pregnancy-associated hypercoagulability may reduce the risk of major peripartum bleeding, the shift toward a procoagulant phenotype also confers an increased risk of VTE.

This baseline pregnancy-associated elevated thromboembolic risk is increased in the presence of additional VTE risk factors. These risk factors may pre-date pregnancy, arise during pregnancy or occur peripartum, highlighting the crucial importance of performing a VTE risk assessment at several 


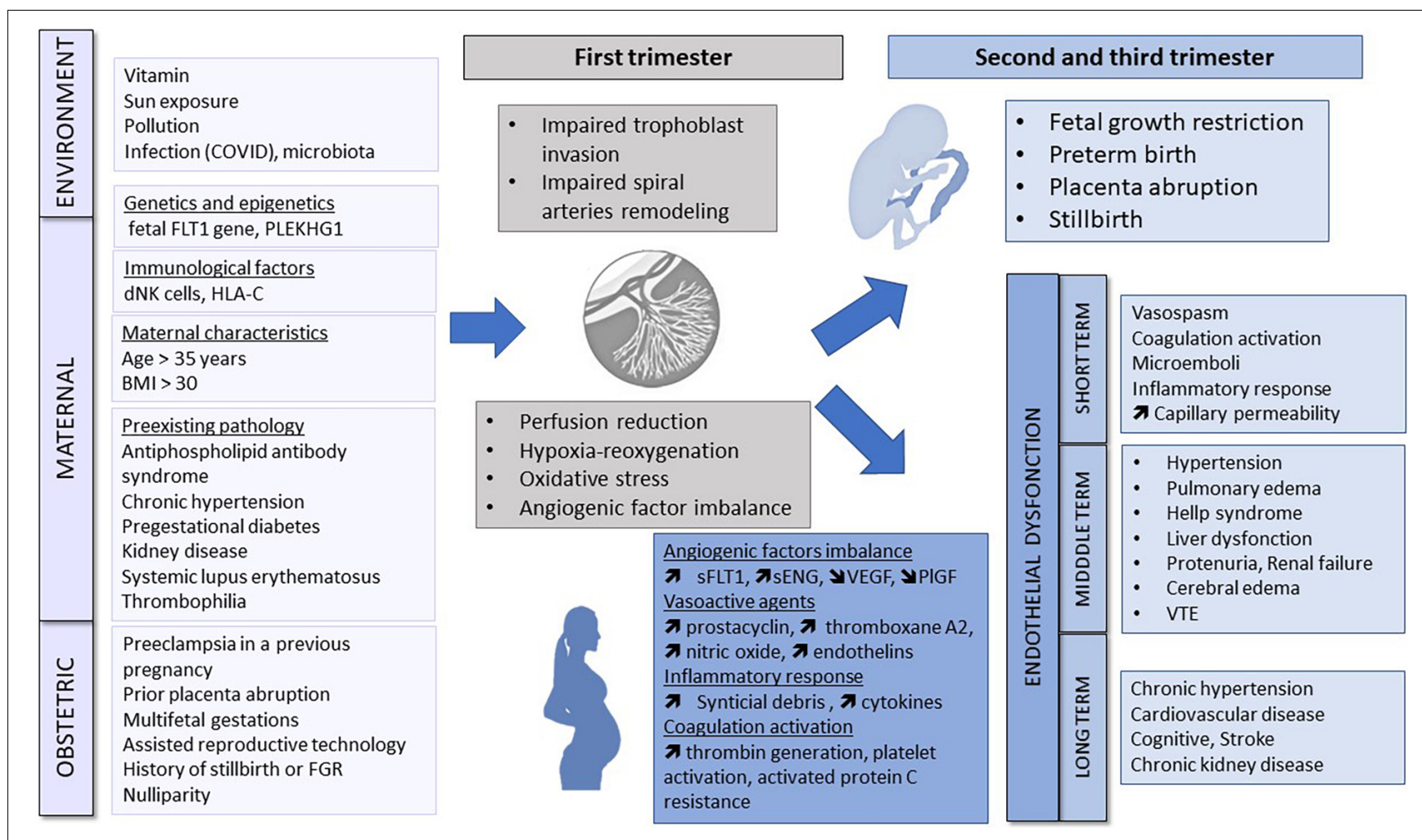

FIGURE 1 | Pathogenesis of pre-eclampsia. Environment, genetic and epigenetic, immunological, maternal and obstetric factors may cause abnormal placentation in the first trimester. Placental ischemia leads to the release of antiangiogenic factors, vasoactive agents, inflammatory response and coagulation activation responsible for endothelial dysfunction and maternal organs dysfunction. FLT1, Fms-like tyrosine kinase; dNK, decidual natural killer; BMI, body mass index; FGR, fetal growth restriction; sFLT1, soluble fms-like tyrosine kinase 1; sENG, soluble endoglin; VEGF, vascular endothelial growth factor; PIGF, placental growth factor; VTE, Venous thromboembolism.

times during pregnancy and at labor and birth. A Norwegian register-based case-control study including 600,000 pregnancies reported a four-fold increased risk of VTE in patients with PET in the postpartum period, however, no association was identified between VTE and PET in antepartum period (63). These results are supported by several studies that reported similar results, assigning greatest VTE risk to the postpartum period (64); mechanisms underlying this observation are not fully characterized (10). Nevertheless PET is still considered as a risk when deciding if a woman needs antenatal thromboprophylaxis in the Royal College of Obstetricians and Gynaecologists (RCOG) guideline (65). An additive effect on the overall postpartum VTE risk was associated with PET complicated by intrauterine growth restriction (IUGR), incurring a seven-fold increased risk (66). In addition, the extent of hemostatic derangement and hypercoagulability appears to be further exacerbated by disease severity and stage; with early-onset PET (EOP) (onset before 34-weeks gestation) having an observed risk of a more severe phenotype (67).

Mechanisms which may underly this prothrombotic phenotype can be attributed to the maternal phase of PET which is characterized by a systemic inflammatory response accompanied by coagulation activation (10). The increased risk of VTE is thought to be multifactorial, involving endothelial dysfunction, coagulation and platelet activation among others (10).

Under normal physiological conditions, the endothelium includes an intact, negatively charged, and non-adhesive glycosaminoglycan layer which acts to inhibit thrombin generation and the adhesion of platelets and leucocytes (68). This endothelial layer expresses a number of anticoagulant proteins such as thrombomodulin (TM), the endothelial protein C receptor (EPCR), and tissue plasminogen activator (tPA) (69). Endothelial dysfunction and damage is extensively reported in PET, and may contribute to impaired activated protein C anticoagulant activity at the endothelial surface and increased exposure of sub-endothelial tissue factor, which is the primary activator of blood coagulation. This, coupled with increased expression of adhesion molecules such as ICAM-1, is postulated to promote the adhesion of inflammatory cells and increased release of endothelial extracellular vesicles (EVs). EVs have also been shown to have a pro-inflammatory and prothrombotic effect activating several pathological signaling pathways on leucocytes, neutrophils, and platelets. Placental-derived factors in PET appear to be key pathological mediators in the process of endothelial damage (67).

Aside from endothelial dysfunction, relative to normal pregnancy, PET is characterized by alterations in circulating 
platelet-derived microparticle (MP) and extracellular vesicle (EV) profiles, which may contribute to the PET-associated VTE risk, although a proven mechanistic association has not yet been defined (67).

\section{PREVENTIVE AND CURATIVE TREATMENT FOR PREECLAMPSIA}

Preeclampsia prevention and treatment continues to be investigated in ongoing studies. Simpler approaches have explored hygienic and dietetic strategies. Measures including bed rest (70), sodium restriction (71), folic acid (72), antioxidant (combined vitamin C and E therapy) (73), fish oil (74), and garlic (75) have failed to demonstrate a clinical benefit. Studies have suggested that exercise (76), and vitamin D (77) supplementation may reduce the PET, however, these studies are hampered by severe methodological limitations and a beneficial effect for these measures has not been proven. A Cochrane review suggests that in areas with a low calcium intake, high-dose calcium supplementation halves the risk of PET (78). Although there are some limitations to the evidence, the World Health Organization endorses the use of supplemental elemental calcium for pregnant women to reduce the PET risk.

Currently, PET prevention centers around low dose aspirin. In 2019, a Cochrane meta-analysis of 77 trials (40,249 women) determined that the risk of pre-eclampsia was $18 \%$ lower with low dose aspirin (95\% CI, 12-23\%) (79). In the ASPRE trial, aspirin $150 \mathrm{mg}$ daily was administered to pregnant women at high-risk of pre-eclampsia as defined by a screening algorithm consisting of clinical, imaging and blood parameters (80). This trial reported a $62 \%$ reduction of the risk of pre-term PET and a $28 \%$ reduction in the combination of pre-term and term PET. In the recently published ASPIRIN randomized control trial (RCT), low-dose aspirin was commenced between 6 and $13+6$ weeks of pregnancy and continued until $36+6$ weeks. A significant reduction in the incidence of preterm birth before 37 weeks in nulliparous women was observed (RR $0.89,95 \%$ CI, 0.81-0.98), along with reduced birth before 34 weeks in women with hypertensive disorders of pregnancy (RR 0.38, 95\% CI, 0.17-0.85). Moreover, perinatal mortality (RR 0.86 ), fetal loss (RR 0.86 ), and early preterm birth before 34 weeks (RR 0.75) was also reduced (81).

Optimal timing of initiation and dose remain uncertain (82). Most evidence supports earlier initiation of aspirin prior to 20 weeks' gestation and ideally prior to 16 weeks at $(83,84)$. Some authors suggest that aspirin administered at bedtime is more efficacious than awakening administration but this concept has not been included in all the recommendations (84-86). The combination of aspirin with low molecular weight heparin (LMWH) is not more efficient than aspirin alone in pregnant women with previous severe preeclampsia diagnosed before 34 weeks of gestation to prevent PET recurrence (87) without maternal or neonatal side effects.

Determining which women should be started on aspirin prophylactically is very challenging. Current evidence shows that no single test predicts pre-eclampsia with sufficient accuracy to be clinically useful (88), and thus signifies the need for improved risk stratification tools.

Preeclampsia without severe features is managed expectantly until 37 weeks, in the presence of severe features in those $<34$ weeks it may be managed expectantly with birth indicated at any time with deterioration of fetal and maternal status. The pharmacological management of mild to moderate hypertension (systolic $<160$ and diastolic $<110$ ) is not currently recommended by the ACOG, as it does not appear to attenuate disease progression and may increase the risk of fetal growth restriction. As this mild to moderate hypertension may be associated with a $4 \%$ risk of stroke, its treatment is still subject to debate (89). Treatment currently revolves around antenatal corticosteroids for fetal lung development in patients $<34$ weeks, and parenteral magnesium sulfate for fetal neuroprotection and maternal seizure prophylaxis; with timely birth of the fetus and placenta remaining the only definitive treatment of PET (12). The efficacy of magnesium sulfate to prevent seizures in women with preeclampsia with severe features and eclampsia is proven but is more debated in cases of moderate preeclampsia $(83,90,91)$.

\section{PREVENTION OF THROMBOEMBOLIC RISK IN PREECLAMPSIA}

Despite the fact that pre-eclampsia complicates a significant number of pregnancies and is the leading cause of morbidity and mortality in pregnancy, therapeutic strategies remain poorly characterized (10). The elevated baseline pregnancyassociated VTE risk is further increased by additional maternal, pregnancy and birth characteristics (such as PET) (9, 21, 92-98), highlighting the importance of VTE risk assessment to detect risk factors in early pregnancy, at birth and if risk factors change (65). VTE risk assessment protocols are based on the cumulative presence of multiple risk factors, of which preeclampsia is one component. Guidelines suggest consideration of thromboprophylaxis, particularly in the postnatal period and in the context of additional risk factors such as early onset PET and intrauterine growth retardation, when the overall VTE risk is $>1-3 \%$ (99). Currently, pharmacological thromboprophylaxis, when it is indicated, is typically achieved through administration of low molecular weight heparin (67). Patient selection is determined based on VTE risk assessment, that should be conducted antepartum and postpartum. However, data supporting the optimal risk threshold at which thromboprophylaxis should be instituted, along with the optimal duration of anticoagulation are lacking, despite how commonly VTE risk factors in the postpartum period arise. As a broad principle, the benefit of pharmacological VTE prophylaxis should outweigh the risk of bleeding and other fetal complications (100). Completing each woman's VTE risk assessment is crucial, particularly in the setting of pre-eclampsia as there is also a proven associated competing hemorrhagic risk. A nationwide cohort study in the Netherlands, reported that $7.4 \%$ of woman with pre-eclampsia developed postpartum hemorrhage, compared to $4.2 \%$ in those without pre-eclampsia (101). Therefore, determining which patients are more likely to 
be affected by bleeding complications is of great importance, and not fully elucidated.

The authors of a 2014 Cochrane review concluded that "there is insufficient evidence on which to base recommendations for thromboprophylaxis during pregnancy (and that) large scale, high-quality randomized trials of currently used interventions are warranted" (102). However, the experience of the PROSPER investigators has demonstrated that conducting RCTs for women with (in this case, postpartum) VTE risk factors can prove extremely challenging $(103,104)$.

Consequently, to date, guideline recommendations are mainly based on expert opinion rather than high-quality evidence (65, 99, 105-107). This can be extremely challenging for care providers, particularly given the competing risks and challenges of pharmacological thromboprophylaxis, which are relatively common and include bleeding, bruising, skin reactions, pain, and in many jurisdictions, high out-of-pocket costs. Data published to date suggest that women who have a strong thrombophilia or a history of previous VTE are likely to benefit from postpartum thromboprophylaxis. However, guideline recommendations regarding thromboprophylaxis strategies for women with more commonly occurring risk factors such as PET vary widely, with much controversy, in light of uncertainty regarding the optimal strategy. This knowledge gap is currently being addressed by the pilot PARTUM randomized controlled trial (Postpartum Aspirin to Reduce Thromboembolism Undue Morbidity; NCT04153760), a pilot trial that will evaluate the feasibility of conducting a larger

\section{REFERENCES}

1. Scheres LJJ, Lijfering WM, Groenewegen NFM, Koole S, de Groot CJM, Middeldorp S, et al. Hypertensive complications of pregnancy and risk of venous thromboembolism. Hypertension. (2020) 75:781-7. doi: 10.1161/ HYPERTENSIONAHA.119.14280

2. Abalos E, Cuesta C, Grosso AL, Chou D, Say L. Global and regional estimates of preeclampsia and eclampsia: a systematic review. Eur J Obstet Gynecol Reprod Biol. (2013) 170:1-7. doi: 10.1016/j.ejogrb.2013.05.005

3. Ramlakhan KP, Johnson MR, Roos-Hesselink JW. Pregnancy and cardiovascular disease. Nat Rev Cardiol. (2020) 17:718-31.

4. Duley L. The global impact of pre-eclampsia and eclampsia. Semin Perinatol. (2009) 33:130-7. doi: 10.1053/j.semperi.2009.02.010

5. Ananth CV, Keyes KM, Wapner RJ. Pre-eclampsia rates in the United States, 1980-2010: age-period-cohort analysis. BMJ. (2013) 347:f6564. doi: 10.1136/ bmj.f6564

6. Brown MA, Magee LA, Kenny LC, Karumanchi SA, McCarthy FP, Saito S, et al. Hypertensive disorders of pregnancy: ISSHP classification, diagnosis, and management recommendations for international practice. Hypertension. (2018) 72:24-43.

7. Obstet Gynecol. Practice bulletin ACOG. No. 202: gestational hypertension and preeclampsia. Obstet Gynecol. (2019) 133:1.

8. English FA, Kenny LC, McCarthy FP. Risk factors and effective management of preeclampsia. Integr Blood Press Control. (2015) 8:7-12. doi: 10.2147/IBPC. S50641

9. Kevane B, Donnelly J, D'Alton M, Cooley S, Preston RJS, Ní Ainle F. Risk factors for pregnancy-associated venous thromboembolism: a review. J Perinat Med. (2014) 42:417-25. doi: 10.1515/jpm-2013-0207

10. Egan K, Kevane B, Ní Áinle F. Elevated venous thromboembolism risk in preeclampsia: molecular mechanisms and clinical impact. Biochem Soc Trans. (2015) 43:696-701. doi: 10.1042/BST20140310

11. Bartsch E, Medcalf KE, Park AL, Ray JG. High risk of pre-eclampsia identification group. Clinical risk factors for pre-eclampsia determined in multinational trial, in which postpartum women with VTE risk factors will be randomized to low-dose aspirin daily or placebo for 6 weeks.

\section{DISCUSSION}

Both PET and VTE remain a leading cause of maternal morbidity and mortality, complicating a significant number of pregnancies $(2,54)$. Underlying pathophysiological mechanisms modulate the baseline hypercoagulable state of pregnancy, influencing both pro and anticoagulant pathways such that some women exhibit and overall increased procoagulant state relative to normal pregnancy, particularly in the post-partum period $(19,20)$. Despite this fact, therapeutic strategies remain poorly characterized (8). Urgent research priorities include personalized risk prediction for PET development and PETassociated VTE risk along with continued refinement of PET prevention strategies. Addressing these knowledge gaps has the potential to result in reduced morbidity and mortality for both mothers affected by PET and their infants.

\section{AUTHOR CONTRIBUTIONS}

TR-B and OE wrote the sections of the manuscript. FN revised the manuscript. All authors contributed to manuscript revision, read, and approved the submitted version.

early pregnancy: systematic review and meta-analysis of large cohort studies. BMJ. (2016) 353:i1753. doi: 10.1136/bmj.i1753

12. Rana S, Lemoine E, Granger JP, Karumanchi SA. Preeclampsia: pathophysiology, challenges, and perspectives. Circ Res. (2019) 124:1094-112.

13. Hansen AT, Schmidt M, Horváth-Puhó E, Pedersen L, Rothman KJ, Hvas AM, et al. Preconception venous thromboembolism and placenta-mediated pregnancy complications. J Thromb Haemost. (2015) 13:1635-41. doi: 10. $1111 /$ jth. 13046

14. Phipps EA, Thadhani R, Benzing T, Karumanchi SA. Pre-eclampsia: pathogenesis, novel diagnostics and therapies. Nat Rev Nephrol. (2019) 15:275-89.

15. Behrens I, Basit S, Melbye M, Lykke JA, Wohlfahrt J, Bundgaard H, et al. Risk of post-pregnancy hypertension in women with a history of hypertensive disorders of pregnancy: nationwide cohort study. BMJ. (2017) 358:j3078. doi: 10.1136/bmj.j3078

16. Stuart JJ, Tanz LJ, Missmer SA, Rimm EB, Spiegelman D, James-Todd TM, et al. Hypertensive disorders of pregnancy and maternal cardiovascular disease risk factor development: an observational cohort study. Ann Intern Med. (2018) 169:224-32. doi: 10.7326/M17-2740

17. Brown MC, Best KE, Pearce MS, Waugh J, Robson SC, Bell R. Cardiovascular disease risk in women with pre-eclampsia: systematic review and metaanalysis. Eur J Epidemiol. (2013) 28:1-19. doi: 10.1007/s10654-013-97626

18. VanWijk MJ, Boer K, Berckmans RJ, Meijers JCM, van der Post JAM, Sturk A, et al. Enhanced coagulation activation in preeclampsia: the role of APC resistance, microparticles and other plasma constituents. Thromb Haemost. (2002) 88:415-20.

19. Greer IA, Aharon A, Brenner B, Gris J-C. Coagulation and placenta-mediated complications. Rambam Maimonides Med J. (2014) 5:e0034. doi: 10.5041/ RMMJ.10168

20. Gris J-C, Bouvier S, Cochery-Nouvellon É, Mercier É, Mousty Ė, PérezMartin A. The role of haemostasis in placenta-mediated complications. 
Thromb Res. (2019) 181(Suppl. 1):S10-4. doi: 10.1016/S0049-3848(19) 30359-7

21. James AH, Jamison MG, Brancazio LR, Myers ER. Venous thromboembolism during pregnancy and the postpartum period: incidence, risk factors, and mortality. Am J Obstet Gynecol. (2006) 194:1311-5. doi: 10.1016/j.ajog.2005. 11.008

22. Middleton P, Shepherd E, Gomersall JC. Venous thromboembolism prophylaxis for women at risk during pregnancy and the early postnatal period. Cochrane Database Syst Rev. (2021) 3:CD001689.

23. Shennan AH, Green M, Chappell LC. Maternal deaths in the UK: preeclampsia deaths are avoidable. Lancet. (2017) 389:582-4. doi: 10.1016/ S0140-6736(17)30184-8

24. Knight M, Tuffnell DA. View from the UK: the UK and Ireland confidential enquiry into maternal deaths and morbidity. Clin Obstet Gynecol. (2018) 61:347-58. doi: 10.1097/GRF.0000000000000352

25. Kaufmann P, Black S, Huppertz B. Endovascular trophoblast invasion: implications for the pathogenesis of intrauterine growth retardation and preeclampsia. Biol Reprod. (2003) 69:1-7. doi: 10.1095/biolreprod.102. 014977

26. Osol G, Moore LG. Maternal uterine vascular remodeling during pregnancy. Microcirculation. (2014) 21:38-47.

27. Roberts JM, Lain KY. Recent insights into the pathogenesis of pre-eclampsia. Placenta. (2002) 23:359-72. doi: 10.1053/plac.2002.0819

28. Rodesch F, Simon P, Donner C, Jauniaux E. Oxygen measurements in endometrial and trophoblastic tissues during early pregnancy. Obstet Gynecol. (1992) 80:283-5.

29. Rajakumar A, Whitelock KA, Weissfeld LA, Daftary AR, Markovic N, Conrad KP. Selective overexpression of the hypoxia-inducible transcription factor, HIF-2alpha, in placentas from women with preeclampsia. Biol Reprod. (2001) 64:499-506. doi: 10.1093/biolreprod/64.2.499

30. Guerby P, Tasta O, Swiader A, Pont F, Bujold E, Parant O, et al. Role of oxidative stress in the dysfunction of the placental endothelial nitric oxide synthase in preeclampsia. Redox Biol. (2021) 40:101861. doi: 10.1016/j.redox. 2021.101861

31. Burton GJ, Jauniaux E. Oxidative stress. Best Pract Res Clin Obstet Gynaecol. (2011) 25:287-99.

32. Fraser R, Whitley GS, Johnstone AP, Host AJ, Sebire NJ, Thilaganathan B, et al. Impaired decidual natural killer cell regulation of vascular remodelling in early human pregnancies with high uterine artery resistance. J Pathol. (2012) 228:322-32. doi: 10.1002/path.4057

33. Hiby SE, Apps R, Sharkey AM, Farrell LE, Gardner L, Mulder A, et al. Maternal activating KIRs protect against human reproductive failure mediated by fetal HLA-C2. J Clin Invest. (2010) 120:4102-10. doi: 10.1172/ JCI43998

34. Carmeliet P. Developmental biology, one cell, two fates. Nature. (2000) 408:45. doi: 10.1038/35040684

35. Cnattingius S, Reilly M, Pawitan Y, Lichtenstein P. Maternal and fetal genetic factors account for most of familial aggregation of preeclampsia: a population-based Swedish cohort study. Am J Med Genet A. (2004) 130A:365-71. doi: 10.1002/ajmg.a.30257

36. Esplin MS, Fausett MB, Fraser A, Kerber R, Mineau G, Carrillo J, et al. Paternal and maternal components of the predisposition to preeclampsia. $N$ Engl J Med. (2001) 344:867-72.

37. Gray KJ, Saxena R, Karumanchi SA. Genetic predisposition to preeclampsia is conferred by fetal DNA variants near FLT1, a gene involved in the regulation of angiogenesis. Am J Obstet Gynecol. (2018) 218:211-8. doi: 10.1016/j.ajog. 2017.11.562

38. McGinnis R, Steinthorsdottir V, Williams NO, Thorleifsson G, Shooter S, Hjartardottir S, et al. Variants in the fetal genome near FLT1 are associated with risk of preeclampsia. Nat Genet. (2017) 49:1255-60. doi: 10.1038/ng. 3895

39. Gray KJ, Kovacheva VP, Mirzakhani H, Bjonnes AC, Almoguera B, DeWan AT, et al. Gene-centric analysis of preeclampsia identifies maternal association at PLEKHG1. Hypertension. (2018) 72:408-16. doi: 10.1161/ HYPERTENSIONAHA.117.10688

40. Williams PJ, Broughton Pipkin F. The genetics of pre-eclampsia and other hypertensive disorders of pregnancy. Best Pract Res Clin Obstet Gynaecol. (2011) 25:405-17. doi: 10.1016/j.bpobgyn.2011.02.007
41. Chesley LC, Cooper DW. Genetics of hypertension in pregnancy: possible single gene control of pre-eclampsia and eclampsia in the descendants of eclamptic women. Br J Obstet Gynaecol. (1986) 93:898-908. doi: 10.1111/j. 1471-0528.1986.tb08006.x

42. Rana S, Cerdeira AS, Wenger J, Salahuddin S, Lim K-H, Ralston SJ, et al. Plasma concentrations of soluble endoglin versus standard evaluation in patients with suspected preeclampsia. PLoS One. (2012) 7:e48259. doi: 10. 1371/journal.pone.0048259

43. Lecarpentier E, Fournier T, Guibourdenche J, Tsatsaris V. [Pathophysiology of preeclampsia]. Presse Med. (2016) 45:631-7.

44. Verdonk K, Visser W, Van Den Meiracker AH, Danser AHJ. The reninangiotensin-aldosterone system in pre-eclampsia: the delicate balance between good and bad. Clin Sci (Lond). (2014) 126:537-44. doi: 10.1042/ cs20130455

45. Stepan H, Schaarschmidt W, Jank A, Verlohren S, Kratzsch J. [Use of angiogenic factors (sFlt-1/PlGF ratio) to confirm the diagnosis of preeclampsia in clinical routine: first experience]. Z Geburtshilfe Neonatol. (2010) 214:234-8. doi: 10.1055/s-0030-1262827

46. Verlohren S, Herraiz I, Lapaire O, Schlembach D, Moertl M, Zeisler H, et al. The sFlt-1/PIGF ratio in different types of hypertensive pregnancy disorders and its prognostic potential in preeclamptic patients. Am J Obstet Gynecol. (2012) 206:58.e1-8. doi: 10.1016/j.ajog.2011.07.037

47. Levine RJ, Lam C, Qian C, Yu KF, Maynard SE, Sachs BP, et al. Soluble endoglin and other circulating antiangiogenic factors in preeclampsia. N Engl J Med. (2006) 355:992-1005. doi: 10.1056/NEJMoa0 55352

48. Stepan H, Unversucht A, Wessel N, Faber R. Predictive value of maternal angiogenic factors in second trimester pregnancies with abnormal uterine perfusion. Hypertension. (2007) 49:818-24. doi: 10.1161/01.HYP. 0000258404.21552.a3

49. Verlohren S, Herraiz I, Lapaire O, Schlembach D, Zeisler H, Calda $\mathrm{P}$, et al. New gestational phase-specific cutoff values for the use of the soluble fms-like tyrosine kinase-1/placental growth factor ratio as a diagnostic test for preeclampsia. Hypertension. (2014) 63:346-52. doi: 10. 1161/HYPERTENSIONAHA.113.01787

50. Verlohren S, Stepan H, Dechend R. Angiogenic growth factors in the diagnosis and prediction of pre-eclampsia. Clin Sci. (2012) 122:43-52. doi: 10.1042/CS20110097

51. Hayes-Ryan D, Khashan AS, Hemming K, Easter C, Devane D, Murphy DJ, et al. Placental growth factor in assessment of women with suspected preeclampsia to reduce maternal morbidity: a stepped wedge cluster randomised control trial (PARROT Ireland). BMJ. (2021) 374:n1857. doi: 10.1136/bmj. n1857

52. Poon LC, Magee LA, Verlohren S, Shennan A, von Dadelszen P, Sheiner E, et al. A literature review and best practice advice for second and third trimester risk stratification, monitoring, and management of pre-eclampsia: compiled by the pregnancy and non-communicable diseases committee of FIGO (the international federation of gynecology and obstetrics). Int $J$ Gynaecol Obstet. (2021) 154(Suppl. 1):3-31. doi: 10.1002/ijgo.13763

53. Askelund KJ, Chamley LW. Trophoblast deportation part I: review of the evidence demonstrating trophoblast shedding and deportation during human pregnancy. Placenta. (2011) 32:716-23. doi: 10.1016/j.placenta.2011. 07.081

54. Peixoto AB, Araujo Júnior E, Ribeiro JU, Rodrigues DBR, Castro ECC, Caldas TMRC, et al. Evaluation of inflammatory mediators in the deciduas of pregnant women with pre-eclampsia/eclampsia. J Matern Fetal Neonatal Med. (2016) 29:75-9. doi: 10.3109/14767058.2014.987117

55. Regal JF, Burwick RM, Fleming SD. The complement system and preeclampsia. Curr Hypertens Rep. (2017) 19:87. doi: 10.1007/s11906-0170784-4

56. Newstead J, von Dadelszen P, Magee LA. Preeclampsia and future cardiovascular risk. Expert Rev Cardiovasc Ther. (2007) 5:283-94.

57. Ijomone OK, Shallie P, Naicker T. Changes in the structure and function of the brain years after pre-eclampsia. Ageing Res Rev. (2018) 47:49-54. doi: 10.1016/j.arr.2018.06.006

58. Sudo M, Yoshita K, Ito Y, Imai N, Iino N, Narita I. Histopathological features of kidney and renal prognosis in patients with preeclampsia. Pregnancy Hypertens. (2021) 25:75-80. doi: 10.1016/j.preghy.2021.05.015 
59. Berg CJ, Callaghan WM, Syverson C, Henderson Z. Pregnancy-related mortality in the United States, 1998 to 2005. Obstet Gynecol. (2010) 116:1302-9.

60. Knight M, Tuffnell D. A view from the UK: the UK and Ireland confidential enquiry into maternal deaths and morbidity. Clin. Obstet. Gynecol. (2018) 61:347-58.

61. Chunilal SD, Bates SM. Venous thromboembolism in pregnancy: diagnosis, management and prevention. Thromb Haemost. (2009) 101:428-38.

62. James AH. Venous thromboembolism in pregnancy. Arterioscler Thromb Vasc Biol. (2009) 29:326-31.

63. Jacobsen AF, Skjeldestad FE, Sandset PM. Incidence and risk patterns of venous thromboembolism in pregnancy and puerperium-a register-based case-control study. Am J Obstet Gynecol. (2008) 198:.e1-7. doi: 10.1016/j.ajog. 2007.08.041

64. Kane EV, Calderwood C, Dobbie R, Morris C, Roman E, Greer IA. A population-based study of venous thrombosis in pregnancy in Scotland 19802005. Eur J Obstet Gynecol Reprod Biol. (2013) 169:223-9. doi: 10.1016/j. ejogrb.2013.03.024

65. Royal College of Obstetricians and Gynaecologists. Reducing the Risk of Venous Thromboembolism during Pregnancy and the Puerperium. London: RCOG (2015).

66. Virkus RA, Løkkegaard E, Lidegaard $\varnothing$, Langhoff-Roos J, Nielsen AK, Rothman KJ, et al. Risk factors for venous thromboembolism in 1.3 million pregnancies: a nationwide prospective cohort. PLoS One. (2014) 9:e96495. doi: 10.1371/journal.pone.0096495

67. Kelliher S, Maguire PB, Szklanna PB, Weiss L, Ewins K, O’Doherty R, et al. Pathophysiology of the venous thromboembolism risk in preeclampsia. Hamostaseologie. (2020) 40:594-604. doi: 10.1055/a-1162-3905

68. Weissgerber TL, Garcia-Valencia O, Milic NM, Codsi E, Cubro H, Nath $\mathrm{MC}$, et al. Early onset preeclampsia is associated with glycocalyx degradation and reduced microvascular perfusion. J Am Heart Assoc. (2019) 8:e010647. doi: 10.1161/JAHA.118.010647

69. Wang M, Hao H, Leeper NJ, Zhu L. Early career committee. thrombotic regulation from the endothelial cell perspectives. Arterioscler Thromb Vasc Biol. (2018) 38:e90-5. doi: 10.1161/ATVBAHA.118.310367

70. Meher S, Abalos E, Carroli G. Bed rest with or without hospitalisation for hypertension during pregnancy. Cochrane Database Syst Rev. (2005) 2005:CD003514. doi: 10.1002/14651858.CD003514.pub2

71. Duley L, Henderson-Smart D, Meher S. Altered dietary salt for preventing pre-eclampsia, and its complications. Cochrane Database Syst Rev. (2005) 19:CD005548.

72. Wen SW, White RR, Rybak N, Gaudet LM, Robson S, Hague W, et al. Effect of high dose folic acid supplementation in pregnancy on pre-eclampsia (FACT): double blind, phase III, randomised controlled, international, multicentre trial. BMJ. (2018) 362:k3478. doi: 10.1136/bmj.k3478

73. Rumbold A, Duley L, Crowther CA, Haslam RR. Antioxidants for preventing pre-eclampsia. Cochrane Database Syst Rev. (2008) 2008:CD004227.

74. Zhou SJ, Yelland L, McPhee AJ, Quinlivan J, Gibson RA, Makrides M. Fish-oil supplementation in pregnancy does not reduce the risk of gestational diabetes or preeclampsia. Am J Clin Nutr. (2012) 95:1378-84. doi: 10.3945/ajcn.111. 033217

75. Meher S, Duley L. Garlic for preventing pre-eclampsia and its complications. Cochrane Database Syst Rev. (2006) 2006:CD006065. doi: 10.1002/14651858. CD006065

76. Barakat R, Pelaez M, Cordero Y, Perales M, Lopez C, Coteron J, et al. Exercise during pregnancy protects against hypertension and macrosomia: randomized clinical trial. Am J Obstet Gynecol. (2016) 214:649.e1-8. doi: 10.1016/j.ajog.2015.11.039

77. Owens MY, Thigpen B, Parrish MR, Keiser SD, Sawardecker S, Wallace K, et al. Management of preeclampsia when diagnosed between 34-37 weeks gestation: deliver now or deliberate until 37 weeks? J Miss State Med Assoc. (2014) 55:208-11.

78. Hofmeyr GJ, Lawrie TA, Atallah ÁN, Torloni MR. Calcium supplementation during pregnancy for preventing hypertensive disorders and related problems. Cochrane Database Syst Rev. (2018) 10:CD001059.
79. Duley L, Meher S, Hunter KE, Seidler AL, Askie LM. Antiplatelet agents for preventing pre-eclampsia and its complications. Cochrane Database Syst Rev. (2019) 2019:CD004659.

80. Rolnik DL, Wright D, Poon LC, O’Gorman N, Syngelaki A, de Paco Matallana $\mathrm{C}$, et al. Aspirin versus placebo in pregnancies at high risk for preterm preeclampsia. N Engl J Med. (2017) 377:613-22. doi: 10.1056/nejmoa1704559

81. Hoffman MK, Goudar SS, Kodkany BS, Metgud M, Somannavar M, Okitawutshu J, et al. Low-dose aspirin for the prevention of preterm delivery in nulliparous women with a singleton pregnancy (ASPIRIN): a randomised, double-blind, placebo-controlled trial. Lancet. (2020) 395:285-93. doi: 10. 1016/S0140-6736(19)32973-3

82. Rothwell PM, Cook NR, Gaziano JM, Price JF, Belch JFF, Roncaglioni MC, et al. Effects of aspirin on risks of vascular events and cancer according to bodyweight and dose: analysis of individual patient data from randomised trials. Lancet. (2018) 392:387-99. doi: 10.1016/S0140-6736(18)31133-4

83. Obstet Gynecol. ACOG committee opinion No. 743: low-dose aspirin use during pregnancy. Obstet Gynecol. (2018) 132:e44-52.

84. Roberge S, Nicolaides K, Demers S, Hyett J, Chaillet N, Bujold E. The role of aspirin dose on the prevention of preeclampsia and fetal growth restriction: systematic review and meta-analysis. Am J Obstet Gynecol. (2017) 216:110-20.e6. doi: 10.1016/j.ajog.2016.09.076

85. Hermida RC, Ayala DE, Fernández JR, Mojón A, Alonso I, Silva I, et al. Administration time-dependent effects of aspirin in women at differing risk for preeclampsia. Hypertension. (1999) 34:1016-23. doi: 10.1161/01.hyp.34.4. 1016

86. Hermida RC, Ayala DE, Calvo C, López JE. Aspirin administered at bedtime, but not on awakening, has an effect on ambulatory blood pressure in hypertensive patients. J Am Coll Cardiol. (2005) 46:975-83. doi: 10.1016/j. jacc.2004.08.071

87. Haddad B, Winer N, Chitrit Y, Houfflin-Debarge V, Chauleur C, Bages $\mathrm{K}$, et al. Enoxaparin and aspirin compared with aspirin alone to prevent placenta-mediated pregnancy complications: a randomized controlled trial. Obstet Gynecol. (2016) 128:1053-63. doi: 10.1097/aog.0000000000001673

88. Giannakou K. Prediction of pre-eclampsia. Obstet Med. (2021) 14:1753495X20984015.

89. Martin JN, Thigpen BD, Moore RC, Rose CH, Cushman J, May W. Stroke and severe preeclampsia and eclampsia: a paradigm shift focusing on systolic blood pressure. Obstet Gynecol. (2005) 105:246-54. doi: 10.1097/01.AOG. 0000151116.84113 .56

90. Altman D, Carroli G, Duley L, Farrell B, Moodley J, Neilson J, et al. Do women with pre-eclampsia, and their babies, benefit from magnesium sulphate? The magpie trial: a randomised placebo-controlled trial. Lancet. (2002) 359:187790. doi: 10.1016/s0140-6736(02)08778-0

91. Lancet. Which anticonvulsant for women with eclampsia? Evidence from the collaborative eclampsia trial. Lancet. (1995) 345:1455-63.

92. Lindqvist P, Dahlbäck B, Marsál K. Thrombotic risk during pregnancy: a population study. Obstet Gynecol. (1999) 94:595-9. doi: 10.1016/s00297844(99)00308-7

93. Jacobsen AF, Skjeldestad FE, Sandset PM. Ante- and postnatal risk factors of venous thrombosis: a hospital-based case-control study. J Thromb Haemost. (2008) 6:905-12. doi: 10.1111/j.1538-7836.2008.02961.x

94. Liu S, Rouleau J, Joseph KS, Sauve R, Liston RM, Young D, et al. Epidemiology of pregnancy-associated venous thromboembolism: a population-based study in Canada. J Obstet Gynaecol Can. (2009) 31:611-20. doi: 10.1016/S1701-2163(16)34240-2

95. Danilenko-Dixon DR, Heit JA, Silverstein MD, Yawn BP, Petterson TM, Lohse CM, et al. Risk factors for deep vein thrombosis and pulmonary embolism during pregnancy or post partum: a population-based, casecontrol study. Am J Obstet Gynecol. (2001) 184:104-10. doi: 10.1067/mob. 2001.107919

96. Simpson EL, Lawrenson RA, Nightingale AL, Farmer RD. Venous thromboembolism in pregnancy and the puerperium: incidence and additional risk factors from a London perinatal database. BJOG. (2001) 108:56-60. doi: 10.1111/j.1471-0528.2001.00004.x

97. Sultan AA, West J, Grainge MJ, Riley RD, Tata LJ, Stephansson O, et al. Development and validation of risk prediction model for venous thromboembolism in postpartum women: multinational cohort study. BMJ. (2016) 355:i6253. doi: 10.1136/bmj.i6253 
98. Sultan AA, Tata LJ, West J, Fiaschi L, Fleming KM, Nelson-Piercy C, et al. Risk factors for first venous thromboembolism around pregnancy: a populationbased cohort study from the United Kingdom. Blood. (2013) 121:3953-61. doi: 10.1182/blood-2012-11-469551

99. Bates SM, Greer IA, Middeldorp S, Veenstra DL, Prabulos A-M, Vandvik PO, et al. VTE, thrombophilia, antithrombotic therapy, and pregnancy: antithrombotic therapy and prevention of thrombosis, 9th ed: American College of chest physicians evidence-based clinical practice guidelines. Chest. (2012) 141:e691S-736S. doi: 10.1378/chest.11-2300

100. Mohzari YA, Asdaq SMB, Bamogaddam RF, Alattas K, Asalmi S, Alshuraim RA. Postpartum prophylaxis of venous thromboembolism with anticoagulation: a case report. J Taibah Univ Med Sci. (2021) 16:292-4. doi: 10.1016/j.jtumed.2020.12.016

101. von Schmidt auf Altenstadt JF, Hukkelhoven CWPM, van Roosmalen J, Bloemenkamp KWM. Pre-eclampsia increases the risk of postpartum haemorrhage: a nationwide cohort study in the Netherlands. PLoS One. (2013) 8:e81959. doi: 10.1371/journal.pone.008 1959

102. Bain E, Wilson A, Tooher R, Gates S, Davis L-J, Middleton P. Prophylaxis for venous thromboembolic disease in pregnancy and the early postnatal period. Cochrane Database Syst Rev. (2014) CD001689.

103. Rodger MA, Phillips P, Kahn SR, James AH, Konkle BA, PROSPER Investigators. Low-molecular-weight heparin to prevent postpartum venous thromboembolism. A pilot randomised placebo-controlled trial. Thromb Haemost. (2015) 113:212-6. doi: 10.1160/TH14-060485

104. Rodger MA, Phillips P, Kahn SR, Bates S, McDonald S, Khurana R, et al. Low molecular weight heparin to prevent postpartum venous thromboembolism: a pilot study to assess the feasibility of a randomized, open-label trial. Thromb Res. (2016) 142:17-20. doi: 10.1016/j.thromres.2016.04.004
105. Chan W-S, Rey E, Kent NE, VTE in Pregnancy Guideline Working Group, Chan W-S, Kent NE, et al. Venous thromboembolism and antithrombotic therapy in pregnancy. J Obstet Gynaecol Can. (2014) 36:527-53.

106. Bates SM, Rajasekhar A, Middeldorp S, McLintock C, Rodger MA, James $\mathrm{AH}$, et al. American society of hematology 2018 guidelines for management of venous thromboembolism: venous thromboembolism in the context of pregnancy. Blood Adv. (2018) 2:3317-59. doi: 10.1182/bloodadvances. 2018024802

107. Lindqvist PG, Hellgren M. Obstetric thromboprophylaxis: the Swedish guidelines. Adv Hematol. (2011) 2011:157483. doi: 10.1155/2011/157483

Conflict of Interest: The authors declare that the research was conducted in the absence of any commercial or financial relationships that could be construed as a potential conflict of interest.

The handling editor declared a shared affiliation with one of the authors, TR-B, at the time of review.

Publisher's Note: All claims expressed in this article are solely those of the authors and do not necessarily represent those of their affiliated organizations, or those of the publisher, the editors and the reviewers. Any product that may be evaluated in this article, or claim that may be made by its manufacturer, is not guaranteed or endorsed by the publisher.

Copyright (c) 2022 Raia-Barjat, Edebiri and Ni Ainle. This is an open-access article distributed under the terms of the Creative Commons Attribution License (CC BY). The use, distribution or reproduction in other forums is permitted, provided the original author(s) and the copyright owner(s) are credited and that the original publication in this journal is cited, in accordance with accepted academic practice. No use, distribution or reproduction is permitted which does not comply with these terms. 